\title{
寒地における金属屋根材料の耐候性 WEATHERABILITY OF METALLIC ROOFING MATERIALS IN COLD REGIONS
}

\author{
井上貞弘* \\ Sadahiro INOUE
}

\begin{abstract}
A weathering test was conducted at three regions in Hokkaido for eleven years. Color, weight and gloss were measured and defects were inspected annually.

The data were analyzed statistically and rankings concerning weatherability were decided. The specimens which were consist of aluminum alloy or galvanised steel as substrates with polyvinylidenefluoride as vehicle of baking paints showed best rankings. All population means of these properties increased with the lapse of time throughout the test term. The best rankings were found for Rumoi concerning discoloration, for Rumoi and Kitami concerning gloss decrease and for Sapporo and Kitami concerning maximum defectless terms.
\end{abstract}

\author{
Keywords: metallic roofing materials, weatherability, weight decrease, \\ discoloration, gloss decrease, defects. \\ 金属屋根材料、而候性、質量減少、変色、光沢減少、欠陥。
}

1.はじめに

寒地の戸建住宅の屋根材料が具備すべき条件は下記の とおりである。(1)軽量であること、（2）凍害を受けない こと、(3)不然材料であること、(4)水密性がよいこと、 (5)耐用年数が長いこと、(6)工費が安いこと、(7)施工 性がよいこと、(8)安定供給できること、(9)品質のむら がないこと、など。金属屋根材料はこれらの条件をほぼ 満たすことができる(1) 。そのために、北海道では近年 の新築戸建住宅の $96 \%$ 以上が金属屋根材料で莫かれてい

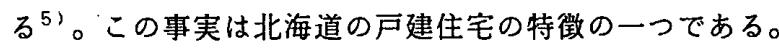
金属屋根材料の劣化要因として、雨、雪、結露、風、気 温、湿度、酸性ガス（ $\mathrm{SO}_{2} 、 \mathrm{NO}_{2} ）$ 、酸性ばい塺、海塩粒 子、紫外線などが上げられる1'。北海道の場合は、下記 の特徵が指摘される。一日の温度変動が大きい地域（北 見など）では屋根面への結露が度々発生し、その分濡れ 時間が長い。降雪量が多い地域（旭川など）では屋根の 積雪が滑落する際に塗膜が摩耗する。この現象は、屋根 から滑落した雪に塗膜の色が付くことで知ることができ
る。無落雪屋根が多い地域（札幌など）では、直ちに流 れ去る雨水と異なり積雪が凍結融解を繰り返しながら年 間約4籄月にわたって屋根の上に帯留し続ける。風が強い 海岸地域（留萌など）では、飛砂による塗膜の摩耗と海 塩粒子による素地の発錆の促進が見られる。北海道では 梅雨や台風の影㪷は極めて少ない。本来、紫外線量が暖 地より少ない上に屋根面が積雪で覆われる期間が長いた め、紫外線による塗膜の劣化は寒地の方が少ない。総体 的に寒地の方が劣化条件が緩やかであり、暖地よりも傷 みが少ないことが知られている11、171。しかし現実には 塗り替え、張り替えの適期を過ぎて塗膜が傷んだり索地 から錆が出た屋根が各所に認められる。

一方、金属屋根材料の耐侯性に関する研究は暖地を中

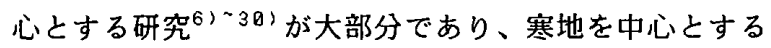

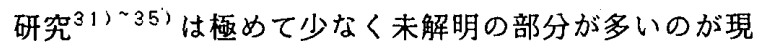
状である。

耐侯性試験による金属屋根材料の劣化の評価項目とし
本論文の一部は, 文献31），32），35）として発表した。

* 北海道立寒地住宅都市研究所 主任研究具 · 博士 (工学)
Senior Researcher, Hokkaido Prefectural Cold Region Housing and Urban Research Institute, Dr. Eng. 
一、光沢度減少率5).7).81.11). 12). 14).21). 24). 25), 27) (32).35)、色差(1.91.11).12).14).21).23).24).27) 28).30) 32).35)、白亜化の程度 6 ). 11).141.20). 21 ). 23).27).301、準膜厚減少率 ${ }^{121}$. 281.341 、質量減少率 (1).12).15).16).19).26).31).32).35) 、顕微鏡観察 ${ }^{7}$ ) 21).26).38)、発錆面積率(6). 18).20)、錆の深さ ${ }^{131}$. (5).16).18).22)、発錆に至るまでの時間10)、染膜中 の特定の元素の量 ${ }^{51}$. 29).33)、酸化增量 ${ }^{13)}$ 、塗膜のふ 〈れ、ひび割れ、はく離の発生状況 ${ }^{6}$ ).91.27).31).32) 34).35)、污れの程度 ${ }^{141.23) .27) .28) .30) な と ゙ か ゙ 上 け ゙ ~}$ られる。

金属屋根材料の劣化機構として、(1)塗膜の紫外線劣化 型、(2)塗膜の付着力の低下型、(3)素地の度食型などを上 げることができるで。染装した金属屋根材料の劣化は、 塗膜の光沢の娍少、塗膜の色調の変化、塗膜の白亜化、 塗膜のふくれ、ひび割れ、はく離、素地の発錆の順序で

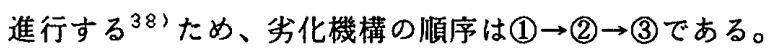
系地自体及び非塗装タイプの金属屋根材料の劣化機構は (3)である。ステンレス鋼、アルミニウム合金、アルミニ ウム合金めっき鋼の場合は表面のち密で㚣定な薄い不動 热被膜による防食作用、要鉊めっき鋼の場合は塩基性炭 酸亜鈶の薄い被膜による防食作用、鐝の一部が麗出した 場合は亜鈶による犠牲防食作用によって、それぞれ内部 が保護される2).38).39)。

本研究では、気象条件がかなり異なる北海道内の3地域 で金属屋根材料の耐侯性試験を行い、データを統計学的 に処理して各性質ごとに劣化の材種差、地域差、期間差 を求め、同時に劣化に対する材種、地域、期間の寄与率 を求めることによって劣化を定量的に評価した。

\section{2. 的侯性試倹}

\section{1. 試験片}

Table 1に示す 27 種類の屋根材料を本研究の試料とした。 1条件に3枚の試験片を使用した。焼付治料の試験片は、 コイルを金属板用カッターで所定の寸法に切断し、四隅 から $15 \mathrm{~mm}$ の部分に直径 $2.5 \mathrm{~mm}$ の穴を空けた。切断面と穴の 部分は各試料に最適な錆止塗料で防錆処理を行った。常 温乾燥型塗料の試験片は、所定の形状に切断し、穴を空 けた溶融严鉊めっき鋼板に、それぞれの深料に十分に慣 れた塗装技能者が、仕様書に従って全面に塗装を行い、 常温で4週間以上硬化させて作製した。非塗装の試験片は、 所定の形状に切断し、穴を空けて作製した。試料の色彩 は、年代にかかわりなく安定した需要を示す青を基準と したが、メーカーの都合で青の製品の在庫がない試料の 場合は最も広く使用されている色彩の製品を本研究に使 用した。試験片の形状寸法をFigure 1に示す。

\section{2. 試験方法}

耐侯性試験の状況をPhoto 1に示す。各試験片の色彩と
してUCS系の a, b, L及びCIE系のX,Y，Zの湘定、光沢度とし て60度鏡面反射法による光沢度の測定、精度0.1mgでの質 量の測定を暴露以前に行った。試験片は正南に向け、水 平に対して 30 度傾斜させて直径 $0.8 \mathrm{~mm}$ のステンレス鋼製針 金で暴露架台に堅固に取り付けた。試験期間は1982年7 月25日から1993年8月26日までの約11年間である。1年ご とに全試験片を暴酷架台から取り外し、レコードキーパ

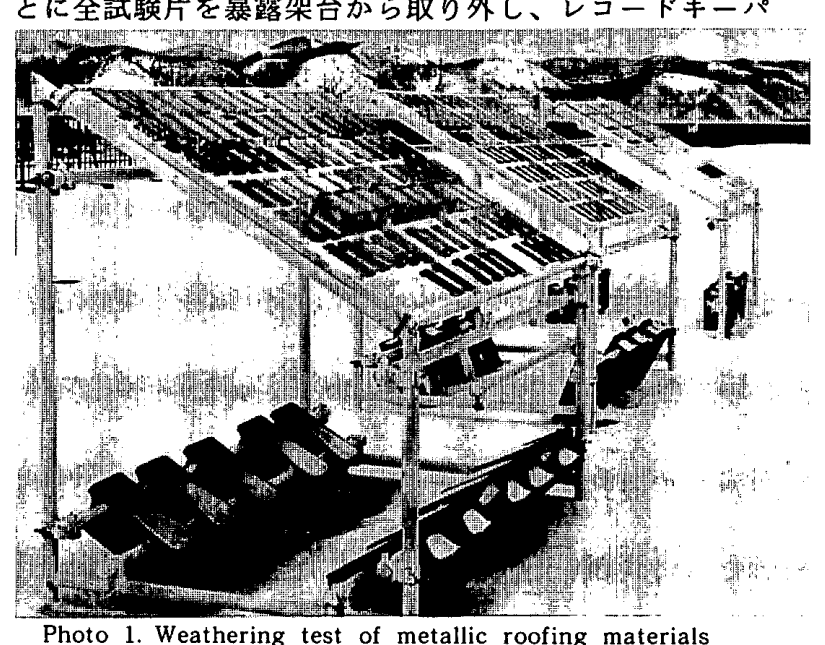

Photo 1. Weathering test of metallic roofing materials

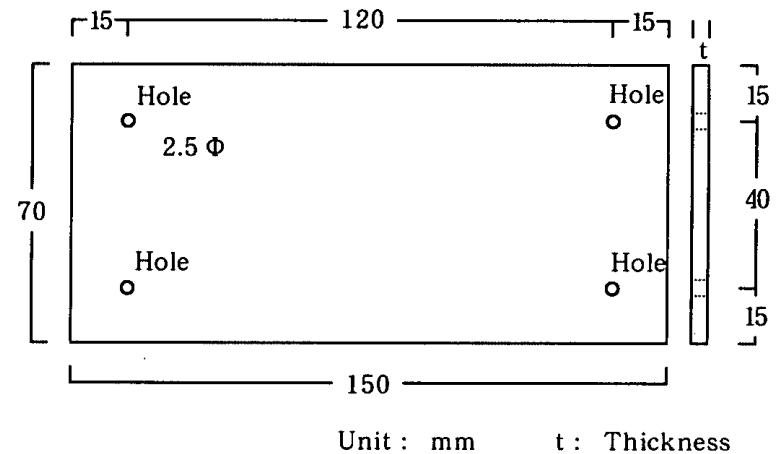

Figure 1. Figure \& dimension of specimens

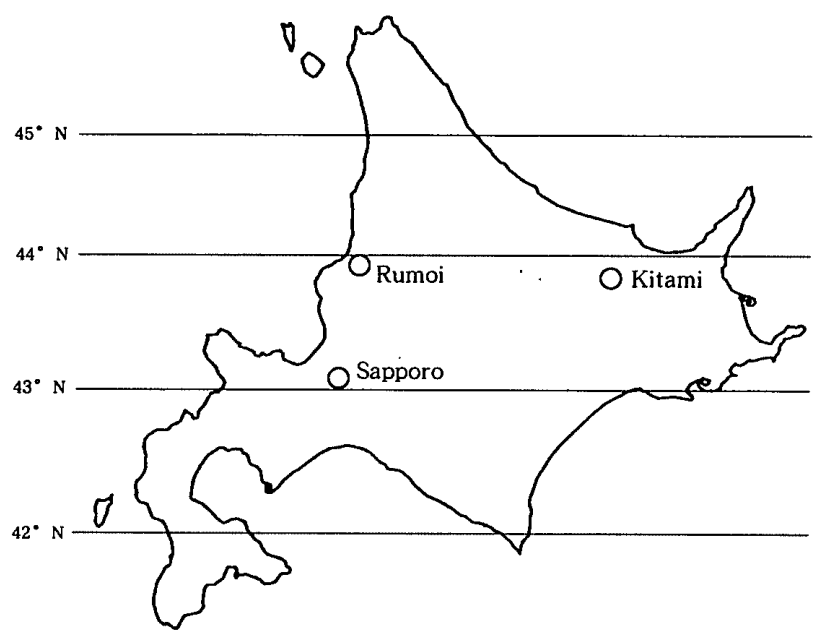

Figure 2. Map of exposure sites 
Table 1. Materials tested

\begin{tabular}{|c|c|c|c|c|c|c|c|c|c|c|c|c|c|}
\hline \multirow[t]{2}{*}{ No. } & \multirow{2}{*}{$\begin{array}{l}\text { Sub - } \\
\text { strates }\end{array}$} & \multirow[t]{2}{*}{ Coatings } & \multicolumn{2}{|c|}{ Thickness } & \multirow[t]{2}{*}{ Color } & \multirow{2}{*}{$\begin{array}{l}\text { Wt } \\
\text { ca. } \\
\text { g } \\
\end{array}$} & \multirow{2}{*}{$\begin{array}{c}\text { Light - } \\
\text { ness }\end{array}$} & \multirow[t]{2}{*}{ Chroma } & \multirow[t]{2}{*}{ Hue. } & \multirow{2}{*}{$\begin{array}{r}\text { White - } \\
\text { ness }\end{array}$} & \multirow[t]{2}{*}{ Gloss } & \multirow{2}{*}{$\begin{array}{l}\text { Hard. } \\
\text { cond. }\end{array}$} & \multirow[t]{2}{*}{ Remarks } \\
\hline & & & $\underset{\mu}{\text { Coat }}$ & $\begin{array}{c}\text { Whole } \\
\mathrm{mm}\end{array}$ & & & & & & & & & \\
\hline 1 & Gl steel & Acrylics & 15 & 0.39 & Green & 33 & 23 & 9 & 0.3 & 4.5 & 66 & Baking & 2 coats \\
\hline 2 & do. & Polyester & 15 & 0.40 & Blue & 31 & 26 & 16 & 2.4 & 12.6 & 46 & do. & do. \\
\hline 26 & do. & do. & 20 & 0.41 & do. & 31 & 30 & 16 & 2.9 & 15.5 & 2 & do. & Gf $\operatorname{mix}$ \\
\hline 16 & do. & do. & 20 & 0.82 & Brick & 34 & 34 & 13 & 1.1 & 6.6 & 0 & do. & $\mathrm{Sd} \operatorname{mix}$ \\
\hline 31 & do. & $\mathrm{Ml}$ - polyester & 30 & 0.46 & Yellow & 35 & 80 & 12 & -5.1 & 50.3 & 12 & do. & 3 coats \\
\hline 5 & do. & Vl-fluoride & 15 & 0.65 & Green & 52 & 43 & 8 & -1.5 & .14 .6 & 10 & do. & 2 coats \\
\hline 32 & do. & do. & 15 & 0.52 & Gray & 40 & 66 & 3 & -0.1 & 43.6 & 13 & do. & do. \\
\hline 4 & do. & $\mathrm{Sl}$ - polyester & 70 & 0.39 & Ocher & 26 & 44 & 23 & 1.6 & 6.8 & 12 & do. & do. \\
\hline 30 & do. & do. & 30 & 0.65 & Gray & 51 & 57 & 2 & -0.6 & 31.0 & 51 & do. & do. \\
\hline 8 & do. & Plastisol & 200 & 0.58 & Blue & 37 & 28 & 19 & 3.0 & 15.6 & 12 & do. & do. \\
\hline 11 & do. & do. & 180 & 0.56 & Gray & 33 & 74 & 2 & -0.7 & 53.5 & 12 & do. & with film \\
\hline 14 & do. & Acrylics & 90 & 0.52 & Blue & 37 & 23 & 22 & 6.2 & 12.9 & 17 & do. & do. \\
\hline 19 & Gl steel & Acrylics & 100 & 0.50 & Blue & 32 & .27 & 18 & 3.0 & 13.8 & 72 & NT dry & 4 coats \\
\hline 27 & do. & do. & 120 & 0.43 & do. & 33 & 27 & 19 & 2.7 & 14.7 & 78 & do. & do. \\
\hline 21 & do. & Urethane & 150 & 0.53 & do. & 36 & 25 & 17 & 2.5 & 12.1 & 58 & do. & do. \\
\hline 22 & do. & Phthalate & 100 & 0.48 & do. & 35 & 27 & 18 & 2.9 & 14.5 & 28 & do. & do. \\
\hline 24 & do. & Drying Bo & 200 & 0.58 & do. & 36 & 29 & 15 & 2.4 & 14.3 & 3 & do: & do. \\
\hline 20 & do. & $\mathrm{Cl}$ rubber & 150 & 0.53 & do. & 36 & 25 & 17 & 2.7 & 12.3 & 78 & do. & do. \\
\hline 28 & do. & Pm cement & 1250 & 1.65 & do. & 57 & 31 & 14 & 1.3 & 14.8 & 2 & do. & do. \\
\hline 9 & Al alloy & Bare & - & 0.48 & Silver & 13 & 59 & 9 & -0.4 & 32.3 & 100 & - & No $\mathrm{Pt}$ \\
\hline 10 & Steel & do. & - & 0.80 & do. & 61 & 70 & 4 & -1.3 & 51.4 & 51 & - & Al Pt \\
\hline 17 & do. & do. & - & 0.58 & Gray & 49 & 54 & 2 & -0.7 & 28.5 & 4 & - & $Z n P t$ \\
\hline 18 & St steel & do. & - & 0.30 & Copper & 24 & 32 & 6 & 1.9 & 7.7 & 100 & - & $\mathrm{Cu} \mathrm{Pt}$ \\
\hline 12 & St steel & SI - polyester & 15 & 0.40 & Choco & 31 & 26 & 2 & 6.2 & 6.1 & 14 & Baking & 2 coats \\
\hline 6 & Al alloy & $\mathrm{Vl}$ - fluoride & 15 & 0.50 & do. & 14 & 33 & 6 & 5.8 & 8.5 & 14 & do. & do. \\
\hline 13 & & Acrylics & 15 & 0.61 & do. & 17 & 34 & 6 & 5.1 & 8.9 & 19 & do. & do. \\
\hline 29 & Wp steel & Linseed oil & 70 & 2.35 & Black & 182 & 25 & 0 & -1.3 & 6.2 & 0 & do. & $\mathrm{Pk}$ \\
\hline
\end{tabular}

Gl : Galvanised

Al : Aluminum

St : Stainless

Wp : Weather proof
Ml: Melamine $\mathrm{Cl}$ : Chlorinated Brick : Brick red Gf: Glass fiber NT: Normal temprature

VI: Vinylidene Pm: Polymer Choco: Chocolate Sd : Sand Hard. cond.: Hardening condition

Sl: Silicone $\mathrm{Zn}$ : Zinc

Bo : Boiling oil $\mathrm{Cu}$ : Copper
Table 2. Conditions of exposure sites (Average values)

\begin{tabular}{|l|l|l|l|l|}
\hline Conditions & Unit & Sapporo & Kitami & Rumoi \\
\hline Max. temp. of day & ${ }^{\circ} \mathrm{C}$ & 12.3 & 11.2 & 10.8 \\
Min. temp. of day & ${ }^{\circ} \mathrm{C}$ & 5.2 & 0.5 & 4.2 \\
Freeze - thaw cycl $/ \mathrm{y}$ & $\mathrm{time}$ & 82 & 92 & 74 \\
Precipitation $/ \mathrm{y}$ & $\mathrm{mm}$ & 993 & 718 & 1124 \\
Duration of sunshine $/ \mathrm{y}$ & $\mathrm{h}$ & 1898 & 2080 & 1744 \\
Wind velocity & $\mathrm{m} / \mathrm{s}$ & 2.4 & 1.7 & 4.9 \\
Temp. change of day & ${ }^{\circ} \mathrm{C}$ & 7.1 & 10.7 & 6.6 \\
SPM conc. $10^{-2}$ & $\mathrm{mg} / \mathrm{m}^{\mathrm{N}}$ & 2.7 & 2.4 & 2.3 \\
SO conc. & $\mathrm{ppm}$ & 8 & 6 & 2 \\
Population: thousands & - & ca.1700 & ca.108 & ca.32 \\
Topography & - & Fan & Basin & Hill \\
Distance to seashore & $\mathrm{km}$ & ca.13 & ca.26 & ca.0.5 \\
\hline
\end{tabular}

Table 3. Measuring apparatus

\begin{tabular}{|c|c|c|}
\hline Properties & Apparatus * & Belative items $* *$ \\
\hline Color & Colorimeter & $\begin{array}{l}\text { Color diff. Lightness } \\
\text { diff. Hue diff. Chroma } \\
\text { diff. Whiteness diff. } \\
\text { Contamination ratio. }\end{array}$ \\
\hline Gloss & Glossmeter & Gloss diff. \\
\hline Weight & $\begin{array}{l}\text { Chemical } \\
\text { balance }\end{array}$ & Weight loss ratio. \\
\hline Thickness & $\begin{array}{l}\text { Thickness } \\
\text { gauge }\end{array}$ & $\begin{array}{l}\text { Coat thickness. } \\
\text { Whole thickness. }\end{array}$ \\
\hline
\end{tabular}

* Electronic devices. ** Items in Table. 1 .

Tables 4 to 11 and 13 . $\%$ diff.:difference.

$y$ :Year. conc. : Concentration.

SPM: Suspended particulated matter. 
一に立て、常温の実験室の棚の上で1週間状態調節を行 い、前述と同一の方法で色彩、光沢度、質量を剆定し、 次に表面の準膜のふくれ、ひび割れ、はく離及び素地の 錆などの欠陷 ${ }^{40)}$ の目視検查を行い、それらがすべて終 了した後、直ちにまた試験片を暴露架台に取り付けた。 試験地域をFigure 2に、各地域の試験期間中の環境条件 をTable 2に、测定装置をTable 3に、それぞれ示す。

金属屋根材料の表面は、耐侯性試験の経過とともに各 種劣化要因の作用によって劣化し、塗膜の一部は白亜化 して失われ、同時に塵あいばい煌が付着する。それに伴 って色彩、光沢、質量が変化し、染膜のはく離などの欠 陷が発生することがある。耐侯性試験後、測定の前に洗 净すると付着している塺あいばい煙は除去することがで きるが、同時に表面の劣化した部分が除去され健全な部 分が露出してしまうので、本研究では劣化した部分の测 定を行うために洗浄しないですべての測定を行った。三 刺激值の一つであるYによって污染の度合を示す方法が

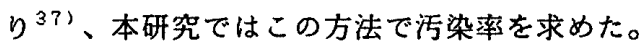

\section{3. 分散分析及ひ F 検定}

各測定値から算出した質量減少率 Weight decrease ratio、色差 Color difference、明度差 Lightness difference、色相差 Hue difference、彩度差 Chroma difference、白度差 Whiteness difference、污染率 Contamination ratio、光沢度差 Gloss differenceの值は、 コンピューターで計算を行う際に容量の範囲内に収める ために下記の平均值を求めて分散分析を行った。0〜1年 :Term 1、2 3年:Term 2、4 5年:Term 3、6〜7年:Term 4、8〜 9年:Term 5、10〜11年:Term 6。光沢度について は、つや消しの試料（No.16、17、24、26、28、29）の测定值 をつや有りの試料の測定值と同等に扱うことは不適当で あり、これらを計算から除外し、つや有りの試料 21 種穎 について分散分析を行った。

耐侯性試験によって欠陥が発生しない最長期間を求め た。その結果を下記のとおり最長無欠陷期間として表現 してこの值の分散分析を行った。0〜1年:Term 0、1〜2年 :Term 1、2 3年:Term 2、3〜 4年:Term 3、4〜5年:Term 4、5〜6年:Term 5、6〜 7年:Term 6、7 8年:Term 7、8 ～9年:Term 8、9〜10年:Term 9、10〜11年:Term 10、11 年以上:Term 11。非塗装製品はすべてTerm 0で董錆が発 生した。非塗装製品を除く 23 種類の試料の値の分散分析 を行った。

分散分析表をTable 4〜Table 12に示す。これらの表 で、交互作用及び誤差の数字は省略した。分散分析表の 記号の意味は下記のとおりである。S:変動 Variation、 $\phi$ :自由度 Degree of freedom、V:不偏分散 Unbiased estimation of variance、 $\mathrm{F}_{\theta}$ :分散比 Ratio of variance、LS:有意水準1\% 0ne per cent level of significance、* : 有意差の存在 Existence of significant dif- -ference。

次に、有意差が認められた場合に $\mathrm{t}$ 検定を行い、有意 水準1\%で差があるか否かを判定した。大きい順序から 差がない值を同一グループとしてランキングした。

耐侯性試験による金属屋根材料の劣化の程度に関する 材料要因として、塗料のビヒクル、顔料、添加剂などの 種類と調合、素地の種類と表面処理方法、塗膜のコート 数、塗膜の硬化温度と硬化時間などを挙げることができ る。本研究の試料はすべて市販の製品であり、製造担当 者以外の者が詳細な調合と製造条件を知ることはできな い。この理由から、本研究では、耐侯性が優れた方から 4ランクまでを材種及び地域ごとに各性質について図示 した。そして各試料をビヒクル、色彩、䒺地の種類、壁 膜の硬化方法など、我々が知り得る要因で表現した。

\section{4. 各性質の材種依存性の㑯问}

各試料ごとの性質のランクをまとめてFigure 3に示す。 亜鉛めっき鋼板を焼付塗料で仕上げた試料（左端の№.1

Table 4. Table of analysis of variance of weight loss ratio $W_{r}=100 \times\left(W_{b}-W_{x}\right) / W_{\theta}$

\begin{tabular}{|l|r|r|l|l|l|}
\hline Factors & $S$ & $\phi$ & $V$ & F日 & LS \\
\hline Materials & 140.24 & 26 & 5.39 & 54.52 & $*$ \\
Terms & 27.98 & 5 & 5.60 & 56.56 & $*$ \\
Regions & 0.32 & 2 & 0.16 & 1.61 & - \\
\hline
\end{tabular}

Table 5. Table of analysis of variance of color difference $\triangle E=\left(\triangle a^{2}+\triangle b^{2}+\triangle L^{2}\right)^{1 / 2}$

\begin{tabular}{|l|l|r|l|l|l|}
\hline Factors & S & \multicolumn{1}{l|}{$\phi$} & V & F & LS \\
\hline Materials & 12546.97 & 26 & 482.58 & 353.46 & $*$ \\
Terms & 2816.77 & 5 & 563.35 & 412.63 & $*$ \\
Regions & 219.91 & 2 & 109.95 & 80.54 & $*$ \\
\hline
\end{tabular}

Table 6. Table of analysis of variance of lightness difference $\triangle \mathrm{L}=\mathrm{L}_{\theta}-\mathrm{L}_{\mathrm{x}}$

\begin{tabular}{|l|l|r|l|l|l|}
\hline Factors & \multicolumn{1}{|l|}{$S$} & $\phi$ & $V$ & $F_{0}$ & LS \\
\hline Materials & 19388.19 & 26 & 745.70 & 579.28 & $*$ \\
Terms & 676.88 & 5 & 135.38 & 105.16 & $*$ \\
Regions & 282.36 & 2 & 141.18 & 109.67 & $*$ \\
\hline
\end{tabular}

Table 7. Table of analysis of variance of hue difference $\triangle H=\left(\triangle E^{2}-\triangle L^{2} a-\triangle C^{2}\right)^{1 / 2}$

\begin{tabular}{|l|r|r|l|r|l|}
\hline Factors & \multicolumn{1}{l|}{$S$} & $\phi$ & $\mathrm{V}$ & \multicolumn{1}{l|}{$\mathrm{F}_{\emptyset}$} & LS \\
\hline Materials & 1713.81 & 26 & 65.92 & 149.53 & $*$ \\
Terms & 311.08 & 5 & 62.22 & 141.14 & $*$ \\
Regions & 23.75 & 2 & 11.87 & 26.94 & $*$ \\
\hline
\end{tabular}


Table 8. Table of analysis of variance of chroma difference $\triangle \mathrm{C}=\mathrm{C}_{\theta}-\mathrm{C}_{\mathrm{x}}$

\begin{tabular}{|l|l|r|r|r|l|}
\hline Factors & \multicolumn{1}{l|}{$S$} & \multicolumn{1}{l|}{$\phi$} & \multicolumn{1}{l|}{ V } & F & LS \\
\hline Materials & 4090.74 & 26 & 157.34 & 241.76 & $*$ \\
Terms & 106.33 & 5 & 21.27 & 32.68 & $*$ \\
Regions & 64.37 & 2 & 32.19 & 49.46 & $*$ \\
\hline
\end{tabular}

Table 9. Table of analysis of variance of whiteness difference $\triangle Z=\left(Z_{\theta}-Z_{\times}\right) / 1.18$

\begin{tabular}{|l|r|r|r|r|l|}
\hline Factors & \multicolumn{1}{|l|}{ S } & \multicolumn{1}{|l|}{$\phi$} & V & Fø & LS \\
\hline Materials & 16238.57 & 26 & 624.56 & 606.18 & $*$ \\
Terms & 93.41 & 5 & 18.68 & 18.13 & $*$ \\
Regions & 151.87 & 2 & 75.94 & 73.70 & $*$ \\
\hline
\end{tabular}

Table 10. Table of analysis of variance of contamination ratio $P_{x}=\left(1-Y_{x} / Y_{0}\right) \times 100$

\begin{tabular}{|l|l|r|l|l|l|}
\hline Factors & S & \multicolumn{1}{|l|}{$\phi$} & V & Fe & LS \\
\hline Materials & 541228.0 & 26 & 20816.46 & 228.73 & $*$ \\
Terms & 70327.2 & 5 & 14065.44 & 154.55 & $*$ \\
Regions & 16926.2 & 2 & 8463.12 & 92.99 & $*$ \\
\hline
\end{tabular}

Table 11. Table of analysis of variance of gloss difference $\triangle G=G_{\emptyset}-G_{\times}$

\begin{tabular}{|l|r|r|r|r|l|}
\hline Factors & S & \multicolumn{1}{l|}{$\phi$} & V & F & LS \\
\hline Materials & 221028.82 & 20 & 11051.44 & 959.19 & $*$ \\
Terms & 40131.40 & 5 & 8026.28 & 696.62 & $*$ \\
Regions & 825.82 & 2 & 412.91 & 35.84 & $*$ \\
\hline
\end{tabular}

Table 12. Table of analysis of variance of maximum defectless terms

\begin{tabular}{|l|l|r|r|r|l|}
\hline Factors & $S$ & \multicolumn{1}{l|}{$\phi$} & $V$ & F & LS \\
\hline Materials & 360.20 & 22 & 16.37 & 2.73 & $*$ \\
Defects & 822.17 & 3 & 274.06 & 45.66 & $*$ \\
Regions & 919.18 & 2 & 459.59 & 76.58 & $*$ \\
\hline
\end{tabular}

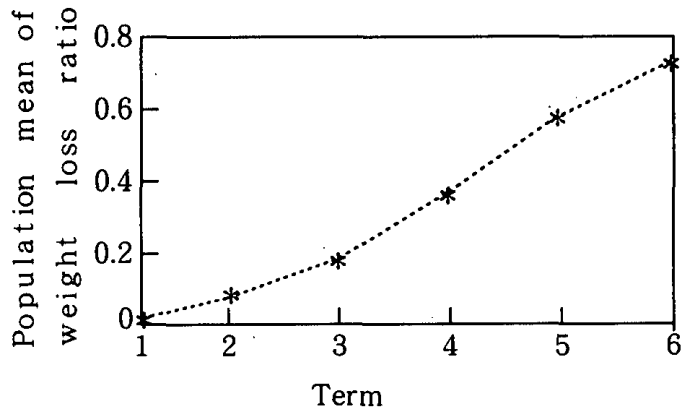

Figure 5. Term dependence of weight loss ratio
から№.14までの12種類）の中では、ふっ化ビニリデン 樹脂系及びメラミンポリエステル樹脂系の焼付㼘料で 仕上げた試料（№.32，№.5，№.31）の耐侯性のランクが特

Weight loss ratio

Color difference

Lightness difference

Hue difference

Chroma difference

Whiteness difference

Contamination ratio

Gloss difference
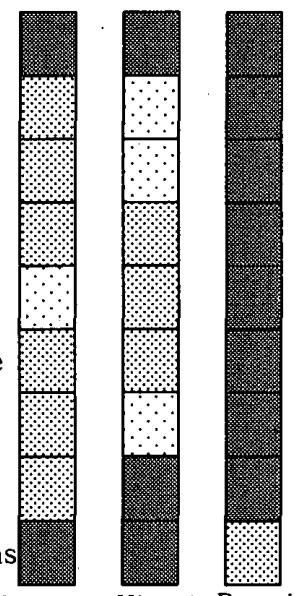

0.09

0.34

0.33

0.19

0.23

0.29

Max. defectless term

Sapporo Kitami Rumoi

0.90

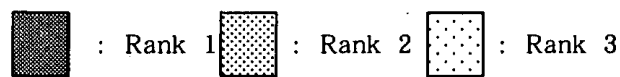

Figure 4 Regional difference

Table 13. The ratio which were classified by best ranking of types of substrates and dryness conditions of paints $(\%)$

\begin{tabular}{|l|c|c|c|}
\hline Substrates & \multicolumn{2}{|c|}{ Galvan. steel } & Others \\
\hline Dryness conditions & Baking & NT dry & Baking \\
\hline Weight loss ratio & 33 & 0 & 100 \\
Color difference & 17 & 0 & 25 \\
Other difference* & 75 & 0 & 33 \\
Whiteness difference & 42 & 0 & 50 \\
Gloss difference & 20 & 0 & 33 \\
Contamination ratio & 42 & 0 & 25 \\
Max.defectless terms & 25 & 29 & 100 \\
\hline
\end{tabular}

* Lightness difference and chroma difference. NT dry:Normal temperature dryness

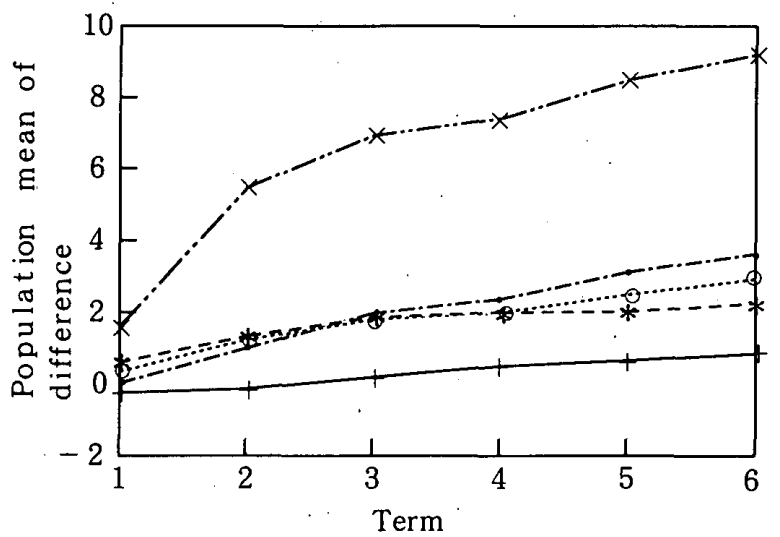

- Lightness difference $\circ$ Hue difference * Chroma difference + Whiteness difference $\times$ Color difference

Figure 6. Term dependence of color variation 


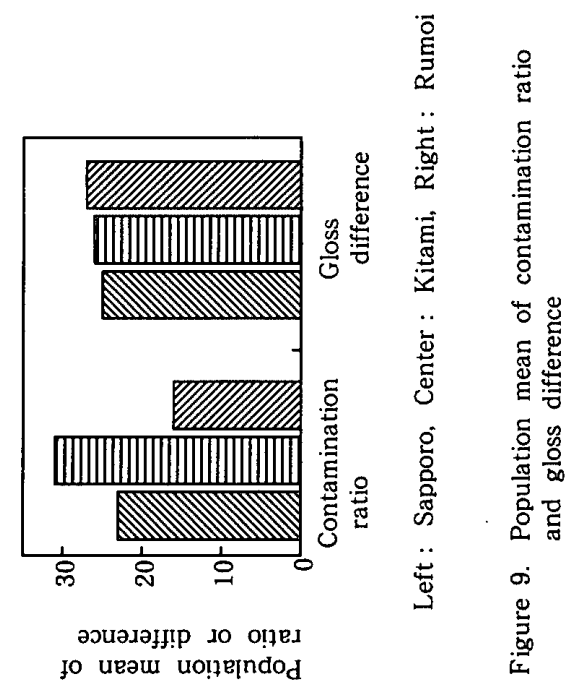

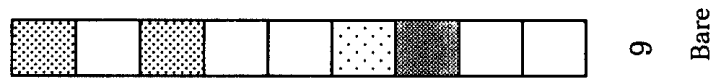
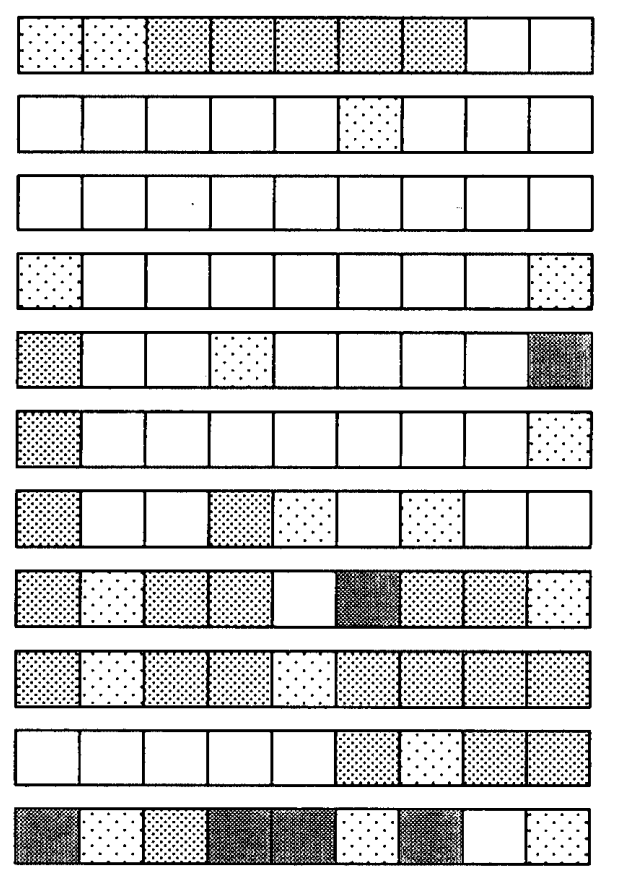

$\stackrel{\infty}{\stackrel{\infty}{*}}$

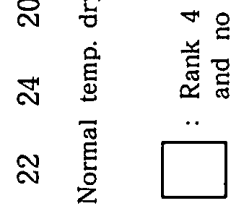

त $\frac{\ddot{\Phi}}{4}$

ล

$\rightarrow \frac{2}{3}$

$\Xi$

$=$

$\infty$

요
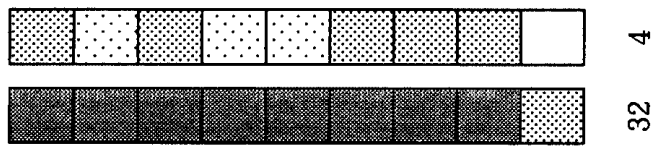

స్ల
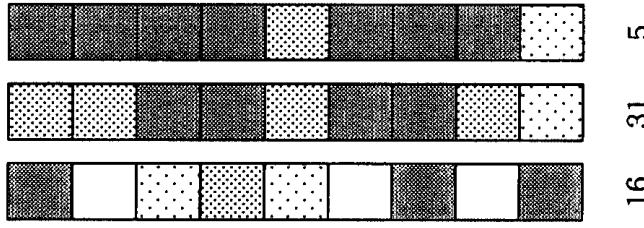

ले

$\stackrel{0}{-1}$
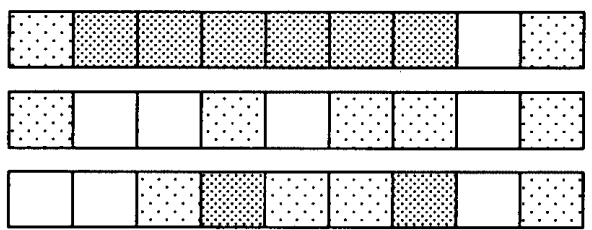

$\stackrel{\circ}{\circ}$

$\sim$

$\rightarrow$

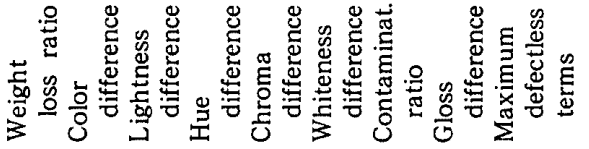
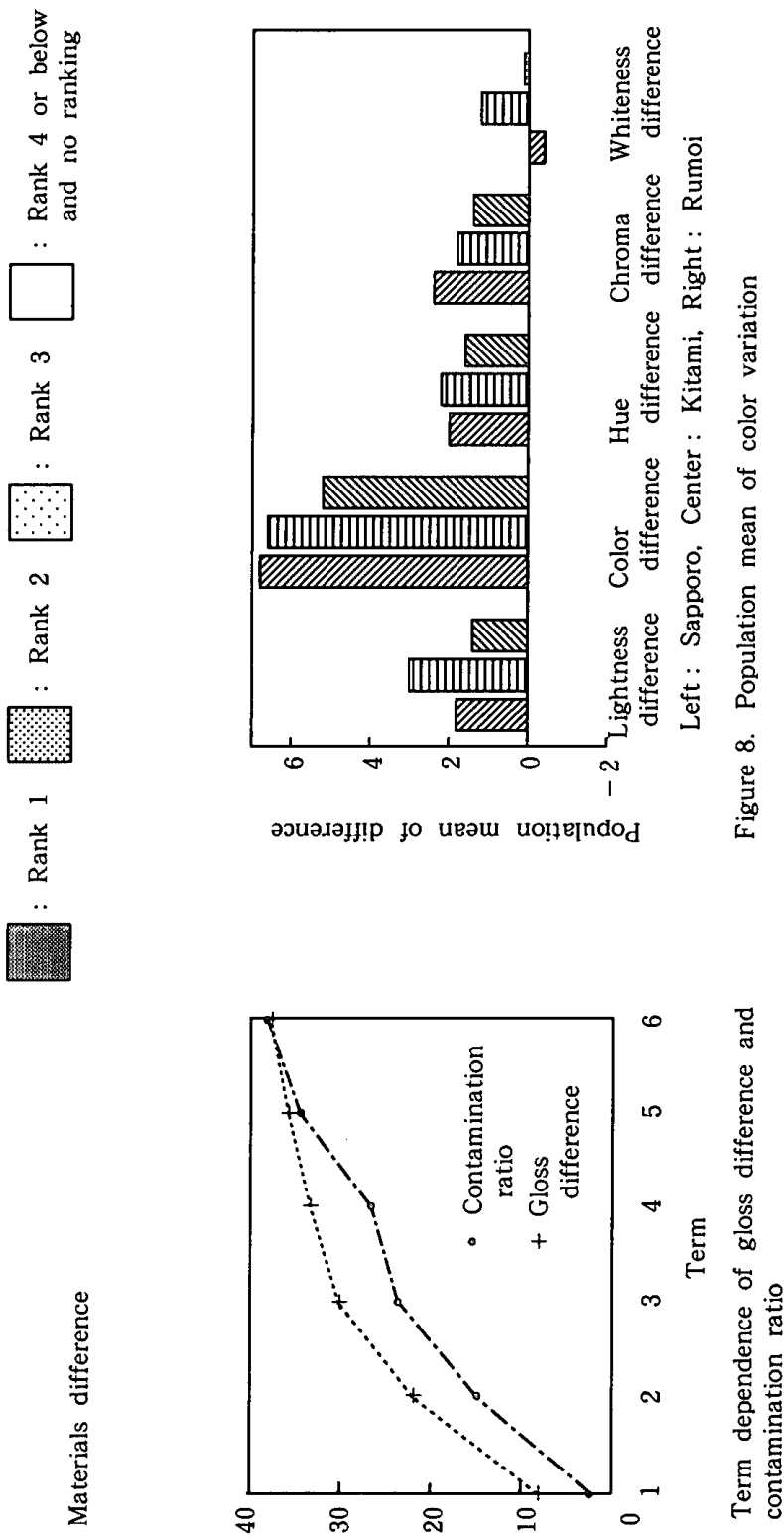

o!ne. jo uвəu uoịejndo d 
に優れている。亜鈆めっき鋼板を常温硬化性塗料で仕上 げた試料（No.19からNo.28までの7種類）の中では、耐侯 性のランクが特に優れた試料は認められない。非塗装金 属板の試料（No.9から№.18 までの4種類）の中では、耐侯 性のランクが特に優れた試料は認められない。その他の 金属板（ステンレス鋼板、アルミニゥム合金板、耐侯性 鋼板）を焼付塗料で仕上げた試料（№.12から右端の No.29 までの4種類) の中では、アルミニゥム合金板をふっ化ビ ニリデン樹脂系焼付渍料で仕上げた試料（№.6）の耐侯性 のランクが特に優れている。

5. 試料の耐矦性と㙰料の便化方法、下地の材種の関俰 試料の性質ごとの最良のランクに属する比率を下地の 材種ごと、塗料の硬化方法ごとにTable 13に示す。

Table 13から、下地は亜鈶めっき鋼板以外の板（ステン レス鋼板、アルミニゥム合金板、耐候性鋼板）が、塗料 の硬化方法は焼付塗装が、それぞれ優れていることが判 明した。

\section{6. 各性質の期間侤存性の傾问}

有意差を示すTermをまとめてTable 14に、質量減少率 の母平均の経時変化をFigure 5に、明度差、色差、色相 差、彩度差、白度差の母平均の経時変化をFigure 6に、 污染率、光沢度差の母平均の経時変化をFigure 7に、そ れぞれ示す。これらの図から、各性質の値は全試験期間 を通じて経時的に増加する傾向を示すことが判明した。

\section{7. 各性質の地域依存性の㑯向}

地域ごとの各性質のランクをまとめてFigure 4に、明 度差、色差、彩度差、白度差の母平均の地域依存性を Figure 8k、污染率、光沢度差の母平均の地域依存性を Figure 9に、それぞれ示す。これらの図から、明度差、 白度差、污染率は北見の值が、色差、彩度差は札幌の值 が、それぞれ最も大きいこと、色相差、光沢度差の值は 地域による差が極めて小さいこと、白度差は北見と留萌 の值が正数、札幌の值が負数であることなどが判明した。

\section{8. 各要因の寄与率}

諸性質における各要因の寄与率をまとめてTable 15 に 示す。Table 15から下記の事実が判明した。質量減少率、 色差、明度差、色相差、彩度差、白度差、污染率、光沢 度差の場合は材質の寄与率が格段に大きく、次は期間の 寄与率で、地域の奇与率は極めて小さい。これに対して、 最長無欠陷期間の場合は地域の寄与率が最む大きく、次 は欠陷種の寄与率で、材質の寄与率はかなり小さい。

\section{9. まとめ}

9.1.材種差 (Figure 3)

試料NNo.6（素地:アルミニゥム合金板、ビヒクル:ふっ化
ビニリデン樹脂、色彩: チョコレートブラウン、塗膜硬 化方法: 焼付け) 及び試料№.32（素地:要鈆めっき鋼板、 ビヒクル:ふっ化ビニリデン樹脂、色彩:灰色、塗膜硬 化方法：焼付け）の耐侯性のランクが最す優れている。 試料№.24（索地:亜鈆めっき鋼板、ビヒクル:乾性油、 色彩: 青、塗膜硬化方法: 常温乾燥) 及び試料NNo.20（素 地:髙鉛めっき鋼板、ビヒクル:塩化ゴム、色彩: 青、塗 膜硬化方法: 常温乾燥) の耐侯性のランクが最も劣る。

\section{2. 期間差 (Figures 5〜 7、Table 14)}

最む早く変化が緩やかになるのは白度差（Term 1〜 2）で、次は彩度差（Term 2 3）、色差、明度差、色 相差、污染率（Term 5～6）の順序であり、質量減少率 と光沢度差はTerm 5〜6でも变化が緩やかにならなかっ た。全期間差の約 $62 \%$ に有意差が認められた。

\section{3.地域差 (Figures 4,8 and 9)}

明度差、色差、色相差、彩度差、白度差については 留萌が、光沢度差については留萌、北見が、欠陷につ いては札幌、北見が、それぞれ最すよい耐侯性のラン クに分類された。3地域の中で留萌だけが海塩粒子の 悪影響を受ける距離にある の地域差の原因と考えられる。

Table 14. Term difference

\begin{tabular}{|l|l|l|l|l|l|l|}
\hline Term & 1 & 2 & 3 & 4 & 5 & 0 \\
& $\& 2$ & $\& 3$ & $\& 4$ & $\& 5$ & $\& 6$ & $(0.01)$ \\
\hline Height loss ratio & $*$ & & $*$ & $*$ & $*$ & 0.13 \\
\hline Color difference & $*$ & $*$ & $*$ & $*$ & & 0.47 \\
\hline Lightness difference & $*$ & $*$ & & $*$ & & 0.46 \\
\hline Hue difference & $*$ & $*$ & $*$ & $*$ & & 0.27 \\
\hline Chroma difference & $*$ & & & & & 0.69 \\
\hline Whiteness difference & & & $*$ & & & 0.41 \\
\hline Contamination ratio & $*$ & $*$ & & $*$ & & 4.0 \\
\hline Gloss difference & $*$ & $*$ & $*$ & $*$ & $*$ & 1.6 \\
\hline
\end{tabular}

Symbol * indicates the terms which show significant difference.

Table 15. Contribution ratio(\%) of every factor

\begin{tabular}{|l|r|r|l|}
\hline Properties & $\begin{array}{c}\text { Mater- } \\
\text { ials }\end{array}$ & Terms & Regions \\
\hline Weight loss ratio & 50.5 & 10.1 & 0.0 \\
Color difference & 67.3 & 15.1 & 1.2 \\
Lightness difference & 79.8 & 2.8 & 1.2 \\
Hue difference & 61.0 & 11.1 & 0.8 \\
Chroma difference & 78.3 & 2.0 & 1.2 \\
Whiteness difference & 82.3 & 0.4 & 0.8 \\
Contamination ratio & 67.8 & 8.8 & 2.1 \\
Gloss difference & 74.2 & 13.5 & 0.3 \\
Max. defectless terms & 5.0 & $17.8 *$ & 20.0 \\
\hline
\end{tabular}

The values of error and interaction were omitted. * The value of types of defects. 


\section{謝 辞}

本研究の文献調查、試験及び取りまとめに際して亜銛 鉄板会の御協力を得た。ここに記して謝意を表します。 参考文献

1）亜鉛鉄板会、亜鉛鉄板-着色亜鉊鉄板-性能·構法ハン ドブック.p. 1〜388, 1983 .

2）軽金属協会、アルミニゥムハンドブック、p. 1〜353, 1990 .

3）増原憲一、家電・建材用表面処理鋼板の諸性質之今後 の動向、西山記念技術講座、Vol. 138, p. 211～242, 1991.

4）鋼材俱楽部、明日を創る外装用建材、p. 1 60, 1991 .

5) 工藤博樹、大垣直明、新築住宅の使用材料の地域差に 関する研究・その2、屋根材の地域差とその要因、日本 建築学会大会梗概集·F,p.721 722,1990.

6) C. Low and 0.C. Vorster, Investigations into coatings for weathered galvanised steel roofing. Journal of oil color chemists association, Vol. 55, No.10, p. 901 916, 1972.

7）竹島鋭機、塗装鋼板の耐久性寿命予測法、溎装技術、 Vol. 22, №.3, p. 91 99, 1983

8）橋本博和、松橋俊一、鶴田 裕、鈴木邦臣、富谷義人、 環境条件の異なる各地での屋外暴露による耐久性 比較試験・その3、外装材の暴露 3 年までの結果、日本 建築学会大会梗概集·A.p.673 674, 1987 .

9) D.M. Howell, Metal cladding for roofs and walls: will it meet your needs? Construction and building materials, Vol.1, p. $10 \sim 15,1988$.

10) H. E. Townsent, A. R. Borzillo and W. D. Baker, Performance of Al-Zn alloy coated steel sheet after twenty-two years of atmospheric corrosion testing. Proceedings of 2 nd conference on zinc coat steel sheets, p. 1 11, 1989.

11）西田和生、樫野紀元、金属外装材の耐久性試験・その1、 金属外装材の自然暴露試験 1 年目の結果、日本建築学 会大会梗概集·A.p. 65 66, 1991.

12）新美宣伸、梁装鋼板の特性之動向、銛と亜鉛、Vol.29, №.1, p. $53 \sim 65.1992$.

13）玉川克軌、亜鉣-アルミニゥム合金めっき鋼板の特性、 鉊之亜鉊、 No.165, p. 45 52, 1993.

14）長谷川完、大澤悟、白石章二、表面好理金属板の 耐久性に関する研究·3年間暴露後の状況、日本建築 学会大会梗概集・A.p. 527 528, 1993.

15）達沢浩一郎、ステンレス鋼の耐侯性について、防錆管 理、Vol. 27, №.2, p. 34〜 40.1983.

16）吉井紹泰、西川光昭、名越敏郎、小田一麿、神余隆義、 ステンレス鋼の耐侯性・大気暴露10年間の結果、防鹰 防食協会大会予稿集、p. 312 315, 1984 .

17）特殊鋼材俱楽部、ステンレス鋼の而候性、特殊鋼、 Vol. 41, No.5, p. 16 38. 1992 .

18）西川光昭、足立俊郎、吉井紹泰、沖縄地区での10年間 の大気暴露試験によるステンレス鋼の耐候性、腐食 防食討論会講演集、p. 349〜352,1993.

19）曽根雄二、矢沢好弘、岡 裕、高耐食性ステンレス鋼 屋根材の開発、日本建築学会大会梗概集·A.p. 529 530,1993

20) C. R. Cox, A. M. Sunner and B. G. Nokes, Durability of prepainted aluminum strip. Transactions of Institution of metal finish. Vol. 55, No.3, p. 107 $\sim 111,1977$.
21）松元秀男、星 尚利、アルミニゥム建材の前処理・塗 料·塗装を展望する、工業塗装、No.77、p. 105〜113. 1985 .

22) H. Hetzel, Langzeit-Verhalten von AluminumBlechen:Überprüf ung nach 30 jähriger Bewitterung DDH, Vol. 20, No.106, p. 34 37, 1985.

23）在見三郎、カラーアルミの耐久性、アルトピア、 Vol. 15, No.7, p. 69 71,1985.

24）青山 幹、堀 長生、西尾章男、常乾型了っ素樹脂 塗料の研究・その1・耐侯性、日本建築学会大会梗概 集·A、p. 631 632, 1986 .

25) D.S.D. Northwood, The benefits and use of powder coatings for architectural aluminum, Pigment and resin technology, Vol. 16, No.3. p. $4 \sim 8,1987$.

26) R. G. Mathey, Investigation of the corrosion of aluminum standing-seam roofing at an army facility, P. B. Report, No.86-213378, p. 1 21, 1986.

27）軽金属協会、カラーアルミ・その耐久性・5年間の暴 露試験、軽金属協会資料、p. 5 13,1989.

28）土屋正一、アルミニゥム表面処理材の耐久性·10年 間の大気暴露試験、日本建鉄技術フォーラム梗概 集、Vol. 10, p. 16〜20,1992.

29）森田彰、小林秀行、阿部ゆかり、アルミ建材への ふっ菜樹脂電着塗装技術·3.5年間の屋外暴露試験 アルトピア、Vol.21, No.10, p. 19〜20.1991.

30）藤本博志、長谷川完、大澤 语、白石章二、外装アル 三用塗料の耐久性に関する研究・その $5 \cdot 7$ 年間の屋 外暴露試験、日本建築学会大会梗概集·A、p. 519 520.

31）井上真弘、萬徳昭夫、後藤 茂、小笠原建二、十河哲 也、北海道における薄板状屋根材料の耐侯性・その 1 ・寒地技術シンポジゥム要旨集.p. 223〜228, 1986.

32）井上貞弘、十河哲也、後藤 茂、小川 貢、北海道に おける薄板状屋ね材料の耐侯性・その2、寒地技術 シンポジゥム要旨集、p. 501〜 506.1989.

33) C.H. Sjöström, P. Jernberg and D. Lala, X-ray photoelectron spectroscopy studies of the degradation of $\mathrm{PVF}_{2}$ coatings. Materials and structures, Yol. 24, No.139, p. 3〜12, 1991.

34）伊東敏幸、苫米地 司、星野政幸、積雪地域における 屋根用塗装鋼板の表面劣化に関する研究、日本建築 学会構造系論文集、No.444,p. 7 12.1993.

35) S. Inoue and S. Gotoh, Weatherability of metallic roofing materials for housing in cold regions, Proceedings of 6 th international conference on durability of building materials and components, p. 57 66, 1993.

36）樫野紀元、建築物への海塩粒子影響調查、建築研究 成果撰あらか、№.3、p. 165〜181，1985.

37）㢦高義典、梅本定良、建筑外装材の污染に及ぼす 高さ、方位の影響、日本建築仕上学会大会学術講演 会研究発表論文集.p. 89 92,1993.

38）亜鉛鉄板会、严鉛めっき鋼板・種類と特長、p. $1 \sim 29$, 1982.

39）ステンレス協会、ステンレス建材の手引き、p.1〜 51,1986

40）（財）塗料検查協会、塗膜の評価基準、p. $1 \sim 41$, 1971.

付 記

本研究の耐侯性試験は、著者自身及び後藤 茂氏ほか の多数の研究所員によって実施された。 


\section{英文要約 (Summary)}

\section{Introduction}

The characteristic requisites of roofing materials of detached houses in cold regions are as follows: (1) light weight. (2) superior frost damage resistance. (3) incombustibility. (4) superior watertightness. (5) superior durability. (6) moderate construction cost. (7) easiness of execution. (8) stable supply and (9) uniform qualities. Metallic roofing materials have been using more than 96 percent at newly built detached houses in Hokkaido because they have most of these requisites. The fact is a characteristic feature of detached houses in Hokkaido. Sometimes deteriorated paint films and rust from substrates of metallic roofing materials are found out because of environmental factors such as rain, snow, condensation, wind, temperature, moisture, acidic pollutants $\left(\mathrm{SO}_{2}\right.$, $\mathrm{NO}_{2}$ ), acidic dust and soot, sea salt particles and UV ray accelerate the degradation of metallic roofing materials.

The progress of three types of degradation mechanisms of painted metallic roofing materials are as follows: (1) UV ray degradation of paint films. $\rightarrow$ (2) adhesive strength drop of paint films. $\rightarrow$ (3) corrosion of metallic substrates. The properties to estimate of degree of degradation of metallic roofing materials in literatures are as follows: gloss decrease ratio, color difference, degree of chalking, paint film thickness decrease, weight decrease, variation of surface states with microscopic observation, rusting area ratio, rusting depth, elapsed time till rust occurrence, amount of a specific chemical element of the surfaces, weight increase with oxidation, state of the defects such as blistering, cracking and peeling of paint films and contamination ratio.

\section{Weathering test}

The 27 types of specimens in Table 1 were used in this research. The figure and dimensions of specimens were as shown in Figure 1. For each condition, three specimen pieces were used. Rust-resisting paints were applied to cut and bored parts of substrates. The standard color of the specimens was blue but other colors were also tested when there were no blue goods in stocks at all. The test setup is shown in Photo 1 . All of the specimens were measured the colors of $a, b, L$ in UCS system and X, Y, Z in CIE system, gloss of 60 degree specular reflection and weight with accuracy of $0.1 \mathrm{mg}$ before the weathering test. Then, specimens were faced south, were inclined 30 degrees to level, and were firmly fixed to exposure racks by stainless steel wire that diameter is $0.8 \mathrm{~mm}$. The test term was approximately eleven years from 25 July 1982 to 26 August 1993 . After the conditioning for seven days at normal temperature, color, gloss and weight of all specimens were measured and the defects such as blistering, cracking and peeling of paint films and rusting of metallic substrates were inspected by naked eye, annually. The situation of the exposure sites are shown in Figure 2. The average exposure conditions in whole weathering test term are shown in Table 2. Measuring apparatus and relative items are shown in Table 3.

\section{Calculations}

The data of weight loss ratio, color difference, lightness difference, hue difference, chroma difference, whiteness difference, contamination ratio and gloss difference were divided from Term one to Term six, and were calculated by analysis of variance. The data of maximum defectless terms were divided from Term zero to Term eleven, and were also calculated by analysis of variance. The results of calculations are shown in Tables 4 through 12 except the values of interactions and errors. After the Fexaminations and t-examinations, $\mathrm{d}(\alpha)$ were calculated. 


\section{Results}

The population means were arranged in decreasing order, and rankings were made such that there were no difference between the values belonging to same range. The results are shown in Figure 3 and Table 13 for material difference, Figure 4, Figure 8 and Figure 9 for regional difference, Figures 5 to 7 and Table 14 for term difference, and Table 15 for contribution ratio of each factor.

\section{Material difference}

In the case of the specimens of galvanised steel sheets with baking paints (12 types from No.1 to No.14 of left side in Figure 3), specimen No.32 (vehicle: polyvinylidenefluoride, color: gray) showed best rankings on weatherability, and specimen No.5 (vehicle: polyvinylidenefluoride, color: green) also showed very good rankings. On the other hand, in the case of specimens of galvanised steel sheets with normal temperature dryness paints (seven types from No.19 to No.28 in Figure 3), specimen No.20 (vehicle: chlorinated rubber, color. blue) and specimen No.24 (vehicle: drying boiling oil, color: blue) showed worst rankings. In the case of the specimens without paint (four types from No.9 to No.18 in Figure 3), it was no specimen which showed good rankings. In the case of miscellaneous metallic sheets with baking paints (four types from No.12 to No.29 of right side in Figure 3), specimen No.6 (substrate: aluminum alloy, vehicle: polyvinylidenefluoride, color. chocolate brown) showed best rankings on weatherability.

\section{Term difference}

It was found out that all of the population means of these properties increased with the lapse of time throughout the test term. The order which show gentle variation were whiteness difference (Term 1 2), chroma difference (Term 2 3), color difference as well as lightness difference, hue difference and contamination ratio (Term $5 \sim 6$ ), but weight loss ratio and gloss difference didn't show gentle variation till the end of the weathering test term. About 62 per cent out of all term difference were found to be significant.

\section{Regional difference}

The best rankings were found for Rumoi conceming lightness difference as well as color difference, hue difference, chroma difference and whiteness difference, for Rumoi and Kitami concerning gloss difference, and for Sapporo and Kitami conceming maximum defectless terms. Among environmental conditions in Table 2, most decisive condition is the distance from seashore, that is, only Rumoi has an aggressive influence of sea salt particles, and then, it was found that rankings of Rumoi were more inferior than that of Sapporo and Kitami concerning maximum defectless terms.

\section{Contribution ratios}

In the case of all properties except maximum defectless terms, the order of contribution ratios is as follows: Materials $>$ Terms $>$ Regions. On the other hand, in the case of maximum defectless terms, the order of ones is as follows: Regions $>$ Defects $>$ Materials.

\section{Acknowledgement}

The author wishes to express appreciation to the Japan Galvanised Iron Sheet Association for cooperation in collecting the literatures, in experimentations and in reviewing the research.

\section{Additional remark}

Weathering test of this research was conducted by myself, Mr. Shigeru Gotoh and many other stuffs of our Institute. 